\title{
Growth Comparisons Between Open-pollinated Progeny of Sugar Maple Grown Under Shade and in Full Sunlight
}

\author{
S.L. Clark ${ }^{1}$ and S.E. Schlarbaum ${ }^{2}$ \\ Department of Forestry, Wildlife, and Fisheries, University of Tennessee, \\ P.O. Box 1071, Knoxville, TN 37901
}

Additional index words. Acer saccharum, nursery management, shading effects, progeny effects, first-order lateral roots, root collar diameter

\begin{abstract}
Progeny from two open-pollinated mother trees were grown for 1 year in a commercial tree nursery in Murphy, N.C. Shade cloths were applied to one half of the seed plots from each mother tree and the other half were exposed to full sunlight. Seedlings were fertilized throughout the growing season to increase growth performance for better discernment of progeny and shade effects. Seedlings in shaded plots were significantly taller and had larger root collar diameters (RCD) than unshaded seedlings. An interaction between progeny and shade effects on first-order lateral root number indicates that genetic or other unknown factors were affecting the seedlings' response to changes in light. Results indicate that the use of shade cloths in nurseries may improve seedling quality of 1-0 sugar maple in the southern portion of the species range.
\end{abstract}

In the southern portion of its range, sugar maple (Acer saccharum Marsh.) is primarily grown in commercial nurseries for use as ornamental planting stock. Unfortunately, nursery managers generally do not utilize proven nursery protocols for the production of highquality sugar maple seedlings (Carl, 1982). The objective of this study was to examine progeny and shading effects and interactions on nursery seedling growth.

\section{Materials and Methods}

Experimental material was part of a larger study in which progeny were being grown in the nursery for subsequent use in a progeny test planting. Sugar maple seed were collected from two open-pollinated mother trees in Moore County, Tenn., in Oct. 1998. The mother trees were assumed to be genetically isolated and were separated by $\approx 150 \mathrm{~m}$. The seed from each mother tree were collected within 2 weeks of each other when the majority of the samaras appeared to be ripe (Carl and Snow, 1971; Yawney and Carl, 1968). The seed were floated in ethyl alcohol to separate the empty and filled samaras and empty samaras were discarded.

Received for publication 10 Sept. 2001. Accepted for publication 8 Apr. 2002. This project was partially supported by the Jack Daniel Distillery, Lynchburg, Tenn. We thank Bill Baron from the Vermont Dept. of Forests, Parks and Recreation for his advice on seed collection and handling. We also appreciate early reviews of this manuscript by Charles Tauer and Craig McKinley and from three anonymous reviewers.

${ }^{1}$ Former Research Associate (presently, Graduate Research Fellow, Dept. of Forestry, Oklahoma State Univ.).

${ }^{2}$ James R. Cox Professor of Forest Genetics. To whom reprint requests should be addressed, tel.: 865-9747993.E-mail address: tenntip@utk.edu
Nursery beds were located at a commercial nursery in Murphy, N.C. Before sowing and fertilization application, a composite soil sample of the nursery beds was collected and analyzed. Soil $\mathrm{pH}$ and percent organic matter were 6.5 and 1.2, respectively. The composition of $\mathrm{P}, \mathrm{K}$, and $\mathrm{Ca}$ in parts per million were 44, 93, and 567, respectively. Percent cation saturation was as follows: $\mathrm{K}, 3.7$; Ca, 44.3; $\mathrm{Mg}$ 14.8; $\mathrm{H}$ 36.3; and $\mathrm{Na}$ 1.2.

Nursery beds consisted of a silt-loam composition. Before sowing, triple-super phosphate $(0 \mathrm{~N}-46 \mathrm{P}-0 \mathrm{~K})$, sulfate of potash magnesia $(0 \mathrm{~N}-22 \mathrm{P}-0 \mathrm{~K}-22 \mathrm{~S}-11 \mathrm{Mg})$, gypsum $(23 \mathrm{Ca}-16 \mathrm{~S})$, solubor $(20.5 \mathrm{~B})$, and zinc sulfate $(17.5 \mathrm{~S}-35.5 \mathrm{Zn})$ were applied at 644 , $112,1121,5.6$, and $28.0 \mathrm{~kg} \cdot \mathrm{ha}^{-1}$, respectively. Ammonium sulfate $(21 \mathrm{~N}-0 \mathrm{P}-0 \mathrm{~K}-24 \mathrm{~S})$ was applied every 10-14 d with application rates starting at $30 \mathrm{~kg} \cdot \mathrm{ha}^{-1}$ in mid-May. Rates increased by $\approx 5 \mathrm{~kg} \cdot \mathrm{ha}^{-1}$ with every application until the last application of $75 \mathrm{~kg} \cdot \mathrm{ha}^{-1}$ in late August. During the growing season, sulfate of potash magnesia was applied at $196 \mathrm{~kg} \cdot \mathrm{ha}^{-1}$ once in early July and once in mid-August. All fertilizer was applied by hand.

After separation of empty and filled samaras, seed were sown by hand at a density of 65 to $86 / \mathrm{m}^{2}$. Two seed plots, each consisting of 150 seed from each mother tree, were sown in Nov. 1998. Seed plots were separated by $0.9 \mathrm{~m}$ of empty bed space and the seed were covered with $\approx 0.6 \mathrm{~cm}$ of yellow-poplar (Liriodendron tulipifera $\mathrm{L}$.) sawdust. One seed plot from each mother tree was completely covered on all sides with a $30 \%$ shade cloth after the seeds had germinated in late May, and the shade cloth was left over the plot until the end of the growing season in Oct. 1999. One seed plot from each mother tree was left unshaded. The seedlings were irrigated as necessary during the growing season.
The seed from mother tree 1 and mother tree 2 germinated at a rate of $75 \%$ and $93 \%$, respectively. The causes of the differences in seed germination between the two mother trees is not known, but could be related to poor judgment in determining ripeness of seed.

The seedlings were lifted by shovel to a depth of $30.5 \mathrm{~cm}$ in Jan. 2000. After lifting, root collar diameter $(\mathrm{RCD})$ and height were measured for each seedling. The RCD was measured $2.54 \mathrm{~cm}$ above the root collar using a digital caliper. Swelling often develops at the root collar, and a better estimate of seedling quality can be obtained by measuring slightly above the root collar(Kormanik, 1986; Ruehle and Kormanik, 1986). Seedling height was measured from the root collar to the top of the terminal bud. The number of first-order lateral roots (FOLR), defined as a suberized root stemming from the main tap root and at least $1 \mathrm{~mm}$ in diameter at the proximal end (Kormanik et al., 1989), were counted on each seedling.

Progeny and shade effects and their interactions were analyzed as fixed effects in a $2 \times 2$ factorial design using PROC MIXED (SAS Inst., 1990). The assumption of normality was checked by examining stem and leaf and box plots of the residuals using PROC UNIVARIATE. The FOLR data were transformed by adding one to the value and then calculating the square root. Differences among the least square means were generated using the PDIFF option. An error level of 0.05 was used to indicate significant differences in all tests.

\section{Results}

Differences between progenies were significant for all traits, except FOLR number (Table 1). Progeny from mother tree 1 had significantly larger mean RCD and taller mean height than progeny from mother tree 2 . Shade effects were significant for all traits, but the interaction between shade and progeny was significant for FOLR number. Height and RCD were significantly greater in shaded vs. full sun seed plots by $62 \%(14.6 \mathrm{~cm})$ and $25 \%(1.4$ $\mathrm{mm})$, respectively. Progeny from mother tree 1 averaged 0.9 fewer FOLR, while progeny from mother tree 2 averaged two more FOLR under shade compared to full sun.

\section{Discussion}

The results agree with previous studies that found improved height in bulked seed stock of sugar maple grown under shade (Cunningham, 1965; Logan, 1965). Sugar maple seedlings are highly susceptibility to solar radiation and water stress during the first few years of development (Kriebel, 1957), and shade may provide needed protection during a critical stage of development. Importantly, improvement in height growth due to shading did not appear to be a result of etiolation, as there was a simultaneous increase in RCD growth and FOLR number in progeny from mother tree 2 . 
Table 1. Differences among least square means for progeny and shade treatments and their interactions for sugar maple nursery seedlings; FOLR = first-order lateral roots, $\mathrm{RCD}=$ root collar diameter.

\begin{tabular}{|c|c|c|c|c|}
\hline \multicolumn{2}{|c|}{ Treatment } & \multicolumn{3}{|c|}{ Trait } \\
\hline Progeny & Shade & FOLR number & $\mathrm{RCD}(\mathrm{mm})$ & $\mathrm{Ht}(\mathrm{cm})$ \\
\hline Mother tree 1 & --- & $2.9 \mathrm{a}^{\mathrm{z}}(249)^{\mathrm{y}}$ & $5.9 \mathrm{a}$ & $34.0 \mathrm{a}$ \\
\hline Mother tree 2 & --- & $2.7 \mathrm{a}(310)$ & $6.5 \mathrm{~b}$ & $27.5 \mathrm{~b}$ \\
\hline --- & Shade & $3.1 \mathrm{a}(235)$ & $6.9 \mathrm{a}$ & $38.1 \mathrm{a}$ \\
\hline--- & No shade & $2.5 \mathrm{~b}(324)$ & $5.5 \mathrm{~b}$ & $23.5 \mathrm{~b}$ \\
\hline Mother tree 1 & Shade & 2.4 a (129) & $6.6 \mathrm{a}$ & $42.1 \mathrm{a}$ \\
\hline Mother tree 1 & No shade & $3.3 \mathrm{~b}(120)$ & $5.2 \mathrm{~b}$ & $26.0 \mathrm{~b}$ \\
\hline Mother tree 2 & Shade & 3.7 b (106) & $7.2 \mathrm{c}$ & $34.1 \mathrm{c}$ \\
\hline Mother tree 2 & No shade & 1.7 c (204) & $5.8 \mathrm{~d}$ & $21.0 \mathrm{~d}$ \\
\hline
\end{tabular}

${ }^{\mathrm{z}}$ Means followed by the same letter are not significantly different within progeny treatment effects, shade treatment effects, or within treatment interactions $(\propto \leq 0.05)$

${ }^{\mathrm{y}}$ Number in parenthesis corresponds to number of seedlings used to calculate means for each row.

The interaction between shade and progeny on FOLR number indicates that genetic or unknown environmental influences were affecting root growth response to changes in light. Genetic differences may exist in how resources are allocated throughout the seedling in response to decreased light levels.

Increased replication of progeny and shade treatments would have been beneficial for this study, but only limited experimental material existed when the experiment was initiated. Despite this weakness, the results indicate that shading should be studied more intensively as a nursery industry practice.

The constant fertilization regime used in this study likely accelerated seedling growth and allowed for discernment of shading effects. Compared to previous studies, the seedlings grown without shade in this study were taller than 1-0 seedlings grown using traditional nursery practices (Carl and Yawney, 1977; Stoeckeler and Jones, 1957) and had similar height to seedlings grown using accelerated greenhouse methods (Wood and Hanover, 1981).

\section{Literature Cited}

Carl, C.M., Jr. 1982. Nursery practices, p. 47-52. In: Sugar maple research: Sap production, processing, and marketing of maple syrup. USDA For. Serv. Gen. Tech. Rpt. NE-72.

Carl, C.M., Jr., and A.G. Snow, Jr. 1971. Matura- tion of sugar maple seed. USDA For. Serv. Res. Paper NE-217.

Carl, C.M., Jr., and H.W. Yawney. 1977. Fall versus spring sowing of sugar maple seed in a nursery. Tree Plant. Notes 28(3/4):24-26.

Cunningham, F.E. 1965. Some factors that may influence germination survival, and growth of sugar maple. Univ. of Massachusetts Agr. Expt. Sta. Proc.: 45-47.

Kormanik, P.P. 1986. Lateral root morphology as an expression of sweetgum seedling quality. For. Sci. 32:595-604.

Kormanik, P.P., Ruehle, J.L. and H.D. Muse. 1989. Frequency distribution of lateral roots of 1-0 bare-root white oak seedlings. USDA For. Serv. Res. Note SE-353.

Kriebel, H.B. 1957. Patterns of genetic variation in sugar maple. Ohio Agr. Expt. Sta. Res. Bul. 791.

Logan, K.T. 1965. Growth of tree seedlings as affected by light intensity I. white birch, yellow birch, sugar maple, and silver maple. Canada Dept. of For. Pub. 1121:5-16.

Ruehle, J.L. and P.P. Kormanik. 1986. Lateral root morphology: A potential indicator of seedling quality in northern red oak. USDA For. Serv. Res. Note SE-344.

SAS Institute. 1990. SAS/STAT user's guide: Version 6. SAS Inst., Cary, N.C.

Stoeckeler, J.H. and G.W. Jones. 1957. Forest nursery practice in the Lake States. USDA Agr. Hdbk. no. 110.

Wood, B.W. and J.W. Hanover. 1981. Early genetic differentiation of sugar maple by accelerating seedling growth. Can. J. For. Res. 11:287-290.

Yawney, H.W. and C.M. Carl, Jr. 1968. Sugar maple seed research, p. 115-123. In: Proc. Northeastern area 20th anniversary nurserymen's conference, 11-12 Sept. 1968, Delaware, Ohio. 